\title{
Calcium blockers inhibit cyclosporine A-induced hyperreactivity of vascular smooth muscle cells
}

\author{
GRZEGORZ GRZEŚK ${ }^{1}$, MICHAŁ WICIŃSKI ${ }^{1}$, BARTOSZ MALINOWSKI ${ }^{2}$, ELŻBIETA GRZEŚK ${ }^{3}$, \\ SŁAWOMIR MANYSIAK ${ }^{2}$, GRAŻYNA ODROWĄŻ-SYPNIEWSKA ${ }^{2}$, \\ NASSER DARVISH ${ }^{1}$ and MACIEJ BIERWAGEN ${ }^{4}$
}

\begin{abstract}
Departments of ${ }^{1}$ Pharmacology and Therapeutics, ${ }^{2}$ Laboratory Medicine, ${ }^{3}$ Pediatrics, Hematology and Oncology, and ${ }^{4}$ Neurosurgery and Neurotraumatology, Collegium Medicum, Nicolaus Copernicus University, 85-094 Bydgoszcz, Poland
\end{abstract}

Received December 19, 2011; Accepted March 12, 2012

DOI: $10.3892 / \mathrm{mmr} .2012 .847$

\begin{abstract}
Cyclosporine belongs to the group of the most commonly used immunosuppressants. Hypertension occurs in approximately $30 \%$ of patients treated with this drug. However, the pathogenesis of this occurrence has not been explained to date. The purpose of our study was to clarify the mechanisms leading to the evolution of hypertension induced by cyclosporine $\mathrm{A}(\mathrm{CsA})$. We examined the changes in transmission within receptors and around the receptors. We also aimed to elucidate the mechanisms responsible for averting arterial hyperresponsiveness induced by the drug. Experiments were performed on isolated and perfused tail arteries of Wistar rats. Tissues surrounding the artery were removed and the proximal segment (length of 2-3 cm) was used for cannulation. Cannulated arteries were placed in a $20-\mathrm{ml}$ glass chamber (vertical position). The contraction force in our model was measured by an increased degree of perfusion pressure with a constant flow rate (approximately $1 \mathrm{ml} / \mathrm{min}$ ). The results showed that in the presence of $\mathrm{CsA}$, the concentration-response curves/phenylephrine (PHE) curve shifted to the left. Cyclosporine increased the reactivity of the arteries to PHE. This effect was directly linked to the
\end{abstract}

Correspondence to: Dr Grzegorz Grześk, Department of Pharmacology and Therapeutics, Collegium Medicum, Nicolaus Copernicus University, 9 Skłodowskiej-Curie Street, 85-094 Bydgoszcz, Poland

E-mail: ggrzesk@cm.umk.pl

Abbreviations: AVP, arginine vasopressin; CRCs, concentration response curves; CsA, cyclosporine A; DAG, diacyloglicerole; ER, endoplasmic reticulum; GPCRs, G-protein coupled receptors; $\mathrm{IP}_{3}$, inositol 1,4,5-trisphosphate; $\mathrm{IP}_{3} \mathrm{R}$, inositol 1,4,5-trisphosphate receptor; NF-AT, nuclear factor of activated T lymphocytes; PHE, phenylephrine; $\mathrm{PIP}_{2}$, phosphatidylinositol 4,5-bisphosphate; PKC, protein kinase C; ROC, receptor-operated channel; RyR, rynodine receptor; SMOC, second messanger-operated channel; VOC, voltage-operated channel; VSMCs, vascular smooth muscle cells

Key words: cyclosporine A, vascular smooth muscle cells, receptors reserve, calcium signals, protein kinase C, BayK-8644 increase in the receptor reserve. The analysis of the reactivity of vascular smooth muscle showed that CsA increased the influx of calcium ions from the extracellular to the intracellular area. No difference was found between the contraction triggered by Bay-K8644 in the presence of CsA and the control probe. The increase in perfusion pressure induced by CsA was blocked by L-type calcium channel blockers (nifidipine and diltiazem). The results from our experiments show that CsA increases the reactivity of vessels to the effect of catecholamines. CsA also enhances signal transmission between G-protein coupled receptors (GPCRs) and calcium channels. The activation of protein kinase $\mathrm{C}$ also plays a significant role in this process. Our results suggest that the best choice for the pharmacotherapy of hypertension induced by CsA would be calcium channel antagonists.

\section{Introduction}

Cyclosporine A (CsA) is the most commonly used drug in immunosuppressive therapy after kidneys, liver, heart or bone marrow transplantation (1). The first polypeptide was isolated from the fungus Tolypocladium inflatum. CsA was introduced into clinical practice as a new generation of immunosuppresants in the 1980 's. It is widely used to prevent the rejection of transplanted organs. However, the drug also has toxic effects. The spectrum of the usage of CsA is not limited only to transplantology; it has also been used to treat patients with uveitis - the first effective therapy was documented in 1979 (2,3). CsA has also been used in other cases where conventional treatment has not been effective $(4,5)$.

CsA inhibits the activity of lymphocytes, especially Th and Tc, decreasing the production of pro-inflammatory interleukin (IL)-2. This effect is based on the binding of CsA to the cytosolic protein, cyclophilin of lymphocytes. The complex form of $\mathrm{CsA}$ and cyclophilin binds to the calcium ions, calmodulin and calcineurin $(\mathrm{CN})$. The inhibition of $\mathrm{CN}$ phosphatase activity, which leads to the dephosphorylation of the nuclear factor of activated T lymphocytes (NF-AT), prevents its activation. In this case, the promoter for IL-2 is blocked (6,7). The application of CsA is associated with many side-effects, such as hypertension, renal failure, hepatotoxicity, neurological disorders or cancers, which cannot be eliminated 
to date (8). One of the main reasons for restricting the usage of CsA in certain situations is nephrotoxicity and hypertension in approximately $30 \%$ of patients. However, the mechanism of this action remains unknown (9).

Hypertension caused by immunosuppressants is one of the main risk factors of cardiovascular diseases. High blood pressure persisting for long periods of time may lead to organ complications, atherogenesis, renal failure, heart failure or stroke. Decisions regarding the treatment of hypertension should be based on clinical investigations that include classification of hypertension, presence of organ complication, additional risk factors (intercurrent diseases) and age (9). Due to the similar effectiveness of drugs from five basic groups, the European Society of Hypertension, European Society of Cardiology and Polish Society of Hypertension do not recommend a specific class of hypertension drugs. The effectiveness of treatment depends on the choice of appropriate therapy (mono- or polytherapy), drug dose, interactions between drugs and the tolerance of drug by the patient $(10,11)$.

Role of calcium ions in vascular smooth muscle tone. The contraction of vascular smooth muscle is upregulated by membrane G-protein coupled receptors (GPCRs), which increase phospholipase C (PLC) activity. Vascular receptors which demonstrate pressor effect are as follows: $\alpha_{1}, \mathrm{~V}_{1}, \mathrm{ET}_{\mathrm{A}}$ and $\mathrm{AT}_{1}$. The complex agonist/receptor leads to $\mathrm{G}_{\mathrm{q}}$ protein activation (first order relay). Through the subunit of $\mathrm{G}_{\mathrm{q}}$ protein, PLC is activated. PLC catalyzes the hydrolysis of phosphatidylinositol 4,5-bisphosphate $\left(\mathrm{PIP}_{2}\right)$ to inositol 1,4,5-trisphosphate $\left(\mathrm{IP}_{3}\right)$ and diacyloglicerole (DAG) $(12,13)$.

The activation of protein kinase $\mathrm{C}$ (PKC) is significant in off-receptor signal regulation induced by DAG. There are many isolated izoenzymes of PKC which demonstrate tissue specificity. PKC enhances the contraction of vascular smooth muscle by L-type calcium channel phosporylation. The importance of PKC activation is proven by the fact that phorbol esters, a group of synthetic PKC activators, induce the contraction of vascular smooth muscle (14-18).

Calcium ion homeostasis is upregulated by their passive transport to the intracellular space of the myocyte and through active transport to the endoplasmic reticulum (ER) and extracellular area in cooperation with ion exchangers.

$\mathrm{Ca}^{2+}$ ion concentration inside the myocyte is $\sim 10^{-7} \mathrm{M}$, which contrasts with their high concentration in extracellular fluid $\left(2 \times 10^{-3} \mathrm{M}\right)(20)$. The influx of calcium ions from the extracellular area goes by channels activated via second messanger-operated channel (SMOC), receptor-operated channel (ROC), voltage-operated channel (VOC) (types L, $\mathrm{N}$ and P), Q, R, T and channels dependent on ER $(20,21) . \mathrm{IP}_{3}$ receptors $\left(\mathrm{IP}_{3} \mathrm{Rs}\right)$ activate the influx of $\mathrm{Ca}^{2+}$ ions induced by the increase in the concentration of $\mathrm{IP}_{3}$. The second channel in the ER area is the ryanodine receptor (RyR). At concentrations from $10^{-9}$ to $10^{-6} \mathrm{M} / 1$, ryanodine shows agonistic actions, but at concentrations higher than $10^{-5} \mathrm{M} / 1$, it blocks the receptors $(22,23)$.

Calcium signal modulation depends on proteins which function as the intracellular detectors for these ions. Calmodulin, activated by calcium ions, belongs to this group of proteins. Complex $\mathrm{Ca}^{2+} /$ calmodulin regulates enzyme activity, such as phospholipases or kinases (19,24-26).
The aim of the study was to investigate whether calcium blockers inhibit CsA-induced hyperactivity of vascular smooth muscle cells (VSMCs).

\section{Materials and methods}

Animals. Experiments were performed on isolated, perfused Wistar rat tail arteries. Animals were housed under a 12/12-h light/dark cycle and had unlimited access to food and water. Male rats weighing 250-270 g were narcotized by intraperitoneal injection of $120 \mathrm{mg}$ urethane per $1 \mathrm{~kg}$ of body mass. Rats were sacrificed by stunning and cervical dislocation. CsA was applied intraperitoneally. The study protocol was approved by the local ethics committee. All experiments were carried out in accordance with the United States NIH guidelines [Guide for the Care and Use of Laboratory Animals (1985), DHEW Publication No. (NIH) 8523: Office of Science and Health Reports, DRR/NIH, Bethesda, MD, USA].

Drugs and solutions. CsA (1 and $10 \mathrm{nM}$, or accordingly, 121.6 and $1,216 \mathrm{ng} / \mathrm{ml}$ ) dissolved in ethanol solution $(70 \%)$. Krebs solution contained $\mathrm{NaCl}(71.8 \mathrm{mM} / \mathrm{l}), \mathrm{KCl}(4.7 \mathrm{mM} / \mathrm{l})$, $\mathrm{CaCl}_{2}(1.7 \mathrm{mM} / \mathrm{l}), \mathrm{NaHCO}_{3}(28.4 \mathrm{mM} / \mathrm{l}), \mathrm{MgSO}_{4}(2.4 \mathrm{mM} / \mathrm{l})$, $\mathrm{KH}_{2} \mathrm{PO}_{4}(1.2 \mathrm{mM} / 1)$ and glucose $(11.1 \mathrm{mM} / \mathrm{l})$. All reagents were purchased from the Sigma-Aldrich Chemical Company (Poznan, Poland).

Study design and performance. After dissection from surrounding tissues, a 2-3 cm long segment of rat tail artery was cannulated and connected to a perfusion device. The distal part was weighed with a 500-mg weight and the tail was placed in a 20-ml container filled with oxygenated Krebs solution at $37^{\circ} \mathrm{C}$. The perfusion pressure was continuously measured. We gradually increased the perfusion solution flow using a peristaltic pump up to $0.25-1 \mathrm{ml} / \mathrm{min}$. Vessel contractions induced by phenylephrine (PHE) [an adrenergic $\alpha-1$ receptor, arginine vasopressin (AVP)] and vasopressin (non-selective agonist $\alpha-1$ receptor, $V_{1}, V_{2}$ ) were measured as an increase in perfusion pressure.

Data analysis and statistical procedures. Perfusion pressure was measured on Nyketron 1675 and TZ-21S devices. Concentration response curves (CRCs) were calculated according to the method described by van Rossum $(27,28)$. Maximal response of tissue $\left(\mathrm{E}_{\max }\right)$ was calculated as a percentage of maximal response of PHE or AVP administered in $\mathrm{KCl}$ solution. Half maximal effective concentration $\left(\mathrm{EC}_{50}\right)$ was estimated using classical pharmacological methods with $\mathrm{pD} 2$, the negative logarithm of the $\mathrm{EC}_{50}$. The number of the $\mathrm{CRC}$ and $\mathrm{E}_{\max }$ was used in all calculations estimating the statistical significance.

\section{Results}

PHE, agonist of the $\alpha_{1}$ adrenergic receptor, increased the perfusion pressure, depending on the concentration. The mean perfusate pressure for PHE $\left(10^{-5} \mathrm{M} / \mathrm{l}\right)$ was $92( \pm 6.2) \mathrm{mmHg}$ in perfusate with $\mathrm{Ca}^{2+}$ and $60( \pm 4.3) \mathrm{mmHg}$ in perfusate without $\mathrm{Ca}^{2+}$. CRCs had sinusoidal shape (Fig. 1). CRCs for PHE were compared in the absence and presence of CsA $(1 \mathrm{nM} / \mathrm{l})$. In the 


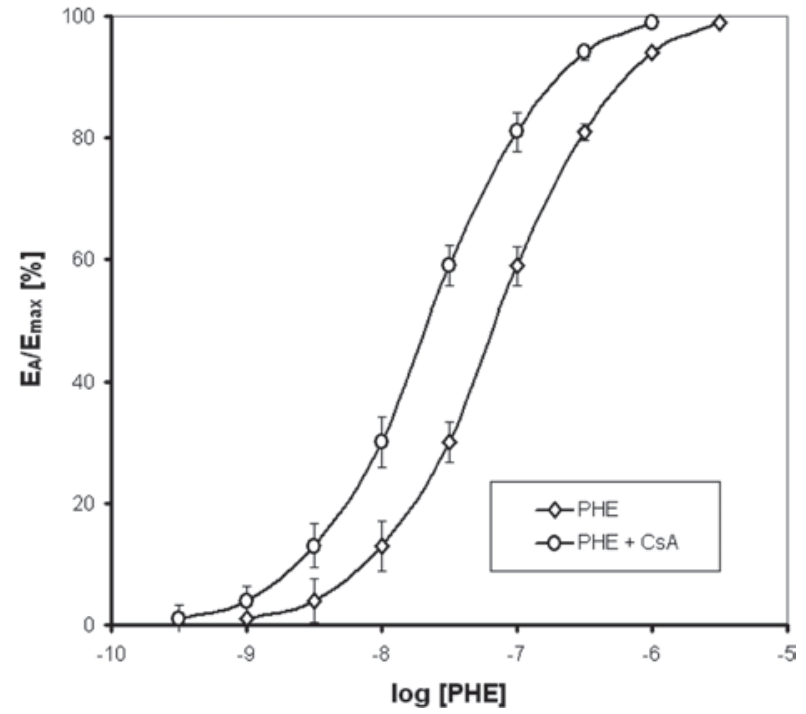

Figure 1. Concentration response curves for phenylephrine (PHE) prior to and after incubation in the presence of cyclosporine-A (CsA) $(1 \mathrm{nM} / \mathrm{l} ; \mathrm{n}=12$, $\mathrm{p}<0.05)$.

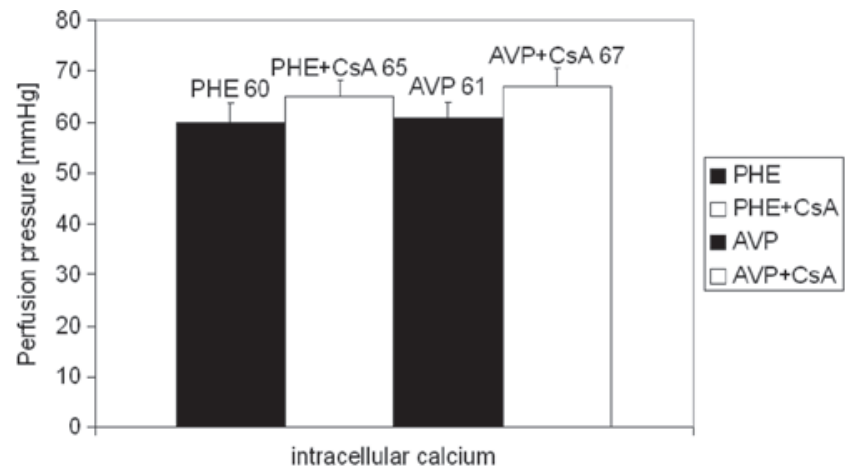

Figure 2. Changes in intracellular calcium levels in the absence or presence of cyclosporine A (CsA) (1 nM/1); n=16 phenylephrine (PHE) vs. PHE + CsA, $\mathrm{p}=\mathrm{ns}$; arginine vasopressin $(\mathrm{AVP})$ vs. AVP $+\mathrm{CsA}, \mathrm{p}=\mathrm{ns}$.

presence of CsA, curves were shifted to the left. A similar shift of CRC and E/RT curves in the presence of CsA was shown in our earlier investigation (stimulated by AVP).

Mobilization of $\mathrm{Ca}^{2+}$ ions from ER of arteries in the absence or presence of $C s A(1 \mathrm{nM} / \mathrm{l})$. In the performed experiment, the contraction of arteries was triggered by PHE $\left(10^{-5} \mathrm{M} / \mathrm{l}\right)$ and AVP $\left(10^{-5} \mathrm{M} / \mathrm{l}\right)$. Values of pressure changes were presented as the means for $n=16 \pm S D$. The experiment was carried out in a fluid without $\mathrm{Ca}^{2+}$. The mean value of perfusion pressure, induced by PHE and AVP was $60( \pm 4.3) \mathrm{mmHg}$ and $61( \pm 4.0) \mathrm{mmHg}$, respectively. During the incubation in the presence of CsA (1 $\mathrm{nM} / 1)$, no significant changes in contraction effect were found for PHE and AVP. Perfusion pressure induced by the action of the drug in both cases was not significantly different compared to the control. Perfusate pressure, after incubation in the presence of CsA, was $65( \pm 3.9) \mathrm{mmHg}$ for PHE and $67( \pm 3.9) \mathrm{mmHg}$ for AVP. Reactivity of the arteries during the incubation in the presence of CsA was not changed. The absence of significant differences in the perfusion pressure

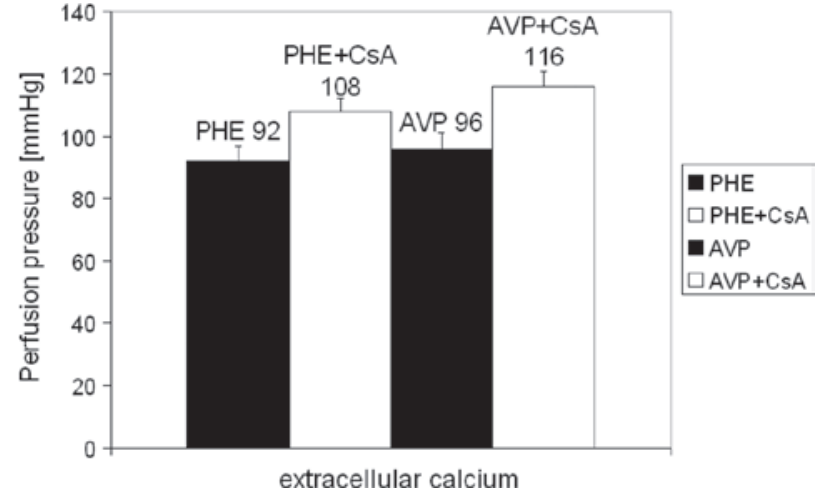

Figure 3. Changes in extracellular calcium levels in the absence or presence of cyclosporine A (CsA) (1 nM/1); n=16, phenylephrine (PHE) vs. PHE + $\mathrm{CsA}, \mathrm{p}=0.0001 ;$ arginine vasopressin (AVP) vs. AVP + CsA, $\mathrm{p}<0.0001$.

proves that CsA does not change the mobilization of intracellular fraction of $\mathrm{Ca}^{2+}$ ions (Fig. 2).

Mobilization of $\mathrm{Ca}^{2+}$ ions from extracellular fraction in the absence or presence of $C s A(1 \mathrm{nM} / \mathrm{l})$. In the performed experiment, the contraction of arteries was triggered by $\mathrm{PHE}\left(10^{-5} \mathrm{M} / \mathrm{l}\right)$ and AVP $\left(10^{-5} \mathrm{M} / \mathrm{l}\right)$. Values of pressure changes were presented as the means for $n=16 \pm$ SD. The experiment was carried out in $\mathrm{Ca}^{2+}$ fluid. The mean value of perfusion pressure induced by PHE and AVP was $92( \pm 6.2) \mathrm{mmHg}$ and $96( \pm 5.2) \mathrm{mmHg}$, respectively. During the incubation in the presence of CsA (1 nM/l), an increase in the contraction effect of PHE was observed. Perfusion pressure induced by the action of the drug increased to $108( \pm 4.2) \mathrm{mmHg}$ and was different compared to the control $(\mathrm{p}<0.0001)$. Increased reactivity of arteries to the pressor action of AVP and PHE demonstrates the mobilization of $\mathrm{Ca}^{2+}$ ions from the extracellular fraction (Fig. 3).

Changes in perfusion pressure induced by PHE before and after application of CsA $(1 \mathrm{nM} / \mathrm{l})$ in the presence of nifedipine, diltiazem and losartan. In the performed experiment, the contraction of arteries was triggered by $\mathrm{PHE}\left(10^{-5} \mathrm{M} / \mathrm{l}\right)$. The control values for PHE and PHE and CsA (1 nM/l) were $92( \pm 6.2) \mathrm{mmHg}$ and $108( \pm 4.2) \mathrm{mmHg}$, respectively. The derivative of 1,4-dihydropyridne, nifedipine $\left(3 \times 10^{-5}\right)$, successfully decreased the perfusion pressure to $87( \pm 5.3) \mathrm{mHg}$ during incubation in the presence of CsA $(\mathrm{p}<0.0001)$. A similar result was found for the benzotiazepine derivative, diltiazem. The mean pressure value after incubation in the presence of CsA was $93( \pm 5.3) \mathrm{mmHg}$ and was $15 \mathrm{mmHg}$ lower than the control $(\mathrm{p}<0.0001)$. Losartan, an angiotensin receptor antagonist, did not reduce artery reactivity in the presence of $\mathrm{CsA}$. The mean pressure value for losartan was $106( \pm 4.3) \mathrm{mmHg}$ and was $2 \mathrm{mmHg}$ lower than the control $(\mathrm{p}=0.2614)$ (Fig. 4).

Changes in perfusion pressure induced by AVP before and after application of CsA $(1 \mathrm{nM} / \mathrm{l})$ in the presence of nifedipine, diltiazem and losartan. In the performed experiment, the contraction of arteries was triggered by AVP $\left(10^{-5} \mathrm{M} / \mathrm{l}\right)$. The control values for AVP alone and AVP plus CsA $(1 \mathrm{nM} / \mathrm{l})$ were $96( \pm 5.2) \mathrm{mmHg}$ and $116( \pm 4.8) \mathrm{mmHg}$, respectively. The derivative of 1,4-dihydropyridne, nifedipine, successfully decreased the perfusion pressure to $91( \pm 4.5) \mathrm{mmHg}$ during 


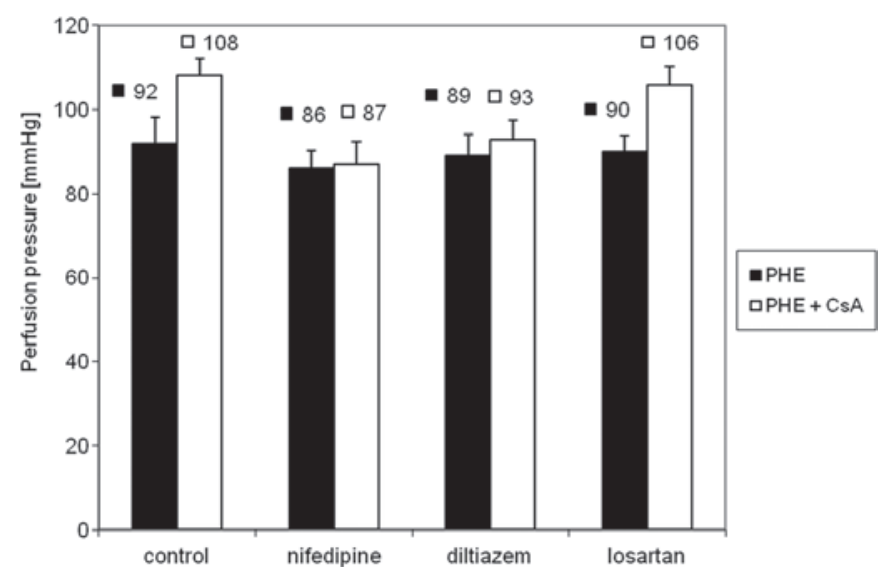

Figure 4. Changes in perfusion pressure induced by phenylephrine (PHE) in the absence or presence of cyclosporine $\mathrm{A}(1 \mathrm{nM} / \mathrm{l})$ for nifedipine, diltiazem and losartan $(\mathrm{n}=16)$. Control vs. nifedipine, $\mathrm{p}<0.0001$; contol vs. diltiazem, $\mathrm{p}<0.0001$; control vs. losartan, $\mathrm{p}=0.2614$.

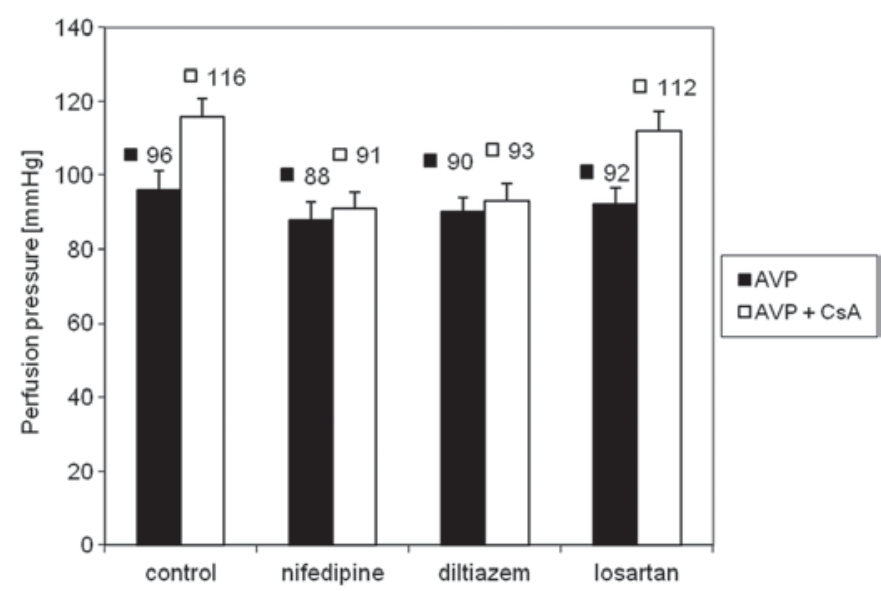

Figure 5. Changes in perfusion pressure induced by arginine vasopressin (AVP) in the absence or presence of cyclospoine A $(1 \mathrm{nM} / 1)$ for nifedipine, dltizem and losartan $(n=16)$. Control vs. nifipine, $\mathrm{p}<0.0001$; control vs. diltiazem, $\mathrm{p}<0.0001$; control vs. losartan, $\mathrm{p}=0.1245$.

incubation in the presence of CsA $(\mathrm{p}<0.0001)$. A similar result was found for the benzotiazepine derivative, diltiazem. The mean pressure value after incubation in the presence of CsA was $93( \pm 5) \mathrm{mmHg}$ and was $23 \mathrm{mmHg}$ lower than the control $(\mathrm{p}<0.0001)$. Losartan did not reduce artery reactivity in the presence of CsA. The mean pressure value for losartan was $112( \pm 5.4) \mathrm{mmHg}$ and was $4 \mathrm{mmHg}$ lower than the control $(\mathrm{p}=0.1245)($ Fig. 5).

Effect of CsA on vasoconstriction induced by BayK-8644. In the performed experiment, vasoconstriction was triggered by the calcium channels agonist, BayK-8644. Arteries were incubated in the presence of CsA (1 nM/l).

To determine how CsA induces hyperreactivity of arteries, two different patterns were made. The first pattern was based on a contraction triggered by BayK-8644 in fluid without $\mathrm{Ca}^{2+}$. The mean perfusion pressure value for BayK 8644 in the presence of CsA was $15( \pm 4.1) \mathrm{mmHg}$ and was not significantly different compared to the control $[12( \pm 3.3) \mathrm{mmHg}]$ $(p=0.1198)$.

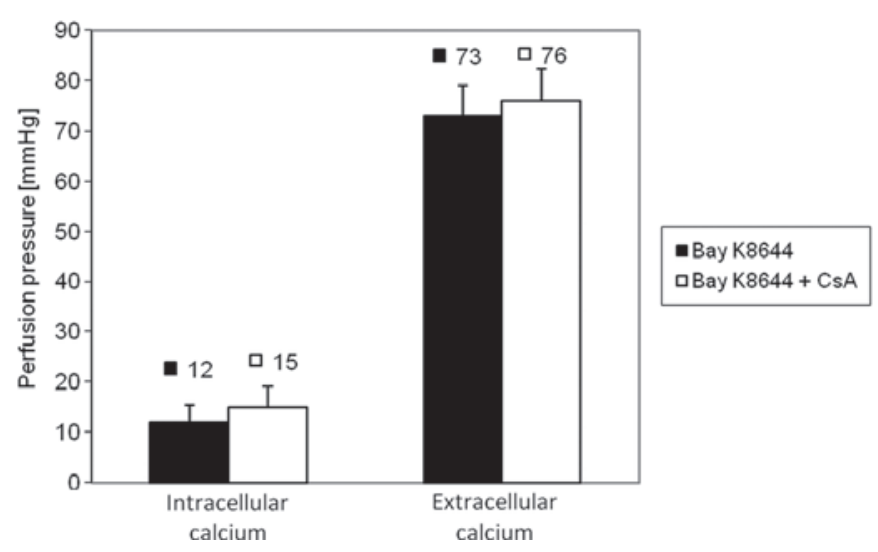

Figure 6. Influence of cyclosporine A (CsA) $(1 \mathrm{nM} / 1)$ on vasoconstriction induced by BayK-8644. Model 1, BayK-8644 vs. BayK-8644 + CsA, p=ns; model 2, BayK-8644 vs. BayK-8644 + CsA, p=ns.

In the second pattern, the arteries were incubated in a fluid with $\mathrm{Ca}^{2+}$. Perfusion pressure induced by BayK-8644 was $73( \pm 5.9) \mathrm{mmHg}$. The incubation of arteries in the presence of CsA did not change their reactivity on contraction triggered by BayK-8644. The mean perfusion pressure value in this pattern was $76( \pm 3.9) \mathrm{mmHg}$ and was not significantly different compared to the control $(\mathrm{p}=0.2375)$ (Fig. 6).

\section{Discussion}

The reactivity of VSMCs is upregulated through the autonomic nervous system. The tension depends on the hormonal activity and local chemical signals. Abnormal vasoreactivity caused by endothelial dysfunction or impaired signal transmission, induces the development of hypertension in the group of patients treated with CsA (29).

Hyperreactivity is the result of complex mechanisms, which lead to the increased concentration of $\mathrm{Ca}^{2+}$ ions in a myocyte. However, vasopressin, norepinephrine and endothelin-1 are ligands for a number of transmembrane metabotropic receptors. The mechanisms of signal transmission in their area are similar and lead to the activation of intracellular calcium influx (30). Moreover, there is a possibility that all receptors bound with the G-protein and $\mathrm{IP}_{3} / \mathrm{DAG}$ cascade are involved in enhancing vasopressin effect via CsA.

No effect of CsA on the mobilization of the intracellular calcium pool suggests that there was a significant increase of transmission within the $\mathrm{IP}_{3} \mathrm{R}$ and ryanodin receptors during the exposure of the arteries to the drug (Fig. 2).

Artery incubation in the presence of CsA increased the influx of calcium ions from the intracellular fraction (Fig. 3). Therefore, the increased intracellular influx from the extracellular compartment may be considered as an important element of hypertension pathogenesis.

In our experiments estimating the vessel contractions induced with the L-type calcium channel agonist, BayK-8644, no significant differences were found in perfusion pressure in both fluids (with and without $\mathrm{Ca}^{2+}$ ) in the presence of CsA (Fig. 6).

Contraction induced by BayK-8644 initiates calcium ion influx from the extracellular area. Apart from vasoconstriction action, BayK-8644 may exert inotropic effects (31). CsA did 
not increase the reactivity of arteries on the pressor action of BayK-8644. The obtained results demonstrate that the drug does not modulate the agonist binding site, and does not change the mobilization of the calcium pool from the ER fraction. In our study, we observed that, in the presence of CsA, the vasosensitivity of the pressor action of PHE and AVP increased. The reason for this hyperreactivity is the enlargement of the receptor reserve pool $\left(\alpha_{1}, V_{1}\right)$. This was confirmed by the higher value of $\mathrm{K}_{\mathrm{A}} / \mathrm{ED}_{50}$ in both cases. Higher receptor reserve in consequence leads to the higher sensitivity of pressure factors $(32,33)$. The data available in the literature show the impact of CsA on the concentration of GPCR receptors.

It was also proven that CsA at a dose of $25 \mathrm{mg} / \mathrm{kg}$ body mass/day applied for 4 weeks induced the expression of mRNA, which encodes the receptor for endothelin-1 (subtype $\mathrm{ET}_{\mathrm{A}}$ ) in the aorta and mesenteric artery by 170 and $176 \%$, respectively. This fact shows an important role of endothelin-1 and its receptor in the pathogenesis of hypertension in a group of patients treated with immunosuppressants. The selective $\mathrm{ET}_{\mathrm{A}}$-FR 139317 receptor antagonist may protect from this action (34). We should also emphasize the role of angiotensin II, whose concentration increases with long-term use (35). Based on our experiments, we conclude that CsA directly increases the activity of $\mathrm{PKC}$, dependent of $\mathrm{Ca}^{2+}$. Shin et al confirmed that the hyperreactivity of PKC ( $\beta$-isoform) plays an important role in the pathogenesis induction, which leads to renal fibrosis in patients treated with CsA (36).

Based on the results in the following study, we may consider a direct influence of CsA on calcium channels. This is due to the reduction or even complete inhibition of vasoconstriction effect of the drug in the presence of the calcium antagonist.

Analyzing the costs of hypertension drugs used after exposure on CsA, it can be concluded that the effective variant in pharmacotherapy of hypertension induced by CsA may be calcium channel antagonists (37). Carrier et al showed that the application of diltiazem by the infusion effectively decreases renal perfusion pressure and may protect from the nephrotoxic effects of the drug. However, even after application of diltiazem, a significant elevation in the concentration of endothelin- 1 from $0.5 \pm 0.4$ to $3.8 \pm 0.6 \mathrm{pg} / \mathrm{ml}$ in the presence of CsA was observed. Although the calcium channel blockade by diltiazem effectively reduced the vasoconstrictive action of the immunosuppressant, they did not prevent the expression of endothelin-1 (38).

The use of the angiotensin receptor antagonist was not effective in the hypertension therapy of patients treated with CsA (Figs. 4 and 5). Hypertension in transplant recipients almost always requires matching three drugs from different therapeutic groups. As a diuretic, patients should receive loop diuretics. If there are no arbitrary indications (coronary artery disease and myocardial infarction), $\beta$-blocker application may be suspended. Observations from past years have shown that $\beta$-blockers foster the growth of body mass in patients, which increases the risk of $\mathrm{T} 2$ diabetes. Calcium antagonists belong to a preferable group of drugs in hypertension therapy after transplantation. It has been proven that those medications reduce the renal failure triggered by infarction and nephrotoxicity caused by calcineurin inhibitors (39). Certain drugs from this group inhibit CYP3A4, which causes the retention of CsA in the blood and necessity of frequent monitoring of the drug concentration
(40). The greatest inhibition of CsA metabolism was demonstrated for verapamil, and lower inhibition was shown for drugs, such as diltiazem, nicardypine and amlodipine. Nifedipine, nitredipine and isradipne did not affect the metabolism of CsA. Calcium channel antagonists belong to the preferable group of drugs used in patients with hyperlipidemia, since contrary to diuretics and $\beta$-blockers, they do not affect the lipid homeostasis (41). Unlike many other drugs used chronically, omission of a single dose of the third-generation calcium antagonist does not cause an increase of blood pressure. Contrary to ACE inhibitors and $\beta$-blockers, amlodipine does not react with non-steroidal anti-inflammatory drugs, and can be used with antibiotics and anti-diabetic medications. Van der Schaaf et al performed experiments in patients with hypertension and kidney transplantation treated with CsA. The particularly beneficial effect of amlodipine at improving renal function was demonstrated. Amlodipine was a better controller of blood pressure (ABPM 111 $\pm 9 \mathrm{mmHg}$ ) than lisinopril (ABPM 115 $\pm 9 \mathrm{mmHg}$ ). Amlodpine enlarged glomerular filtration rate, effective renal plasma flow and decreased renal vascular resistance. These parameters did not differ significantly during therapy with lisinopril (42). Chanard et al proved its superiority over the $\beta$-blocker teratolol. Amlodipine decreased the concentration of uric acid in the plasma from $483 \pm 99$ to $431 \pm 110 \mu \mathrm{mol} / 1$, whereas tetralol increased it from $450 \pm 98$ to $476 \pm 84 \mu \mathrm{mol} / 1$ (43).

In conclusion, CsA increases vascular reactivity by enhancing signal transmission between GPCR and calcium channels. The effect of CsA is also significantly inhibited by the calcium blockers, nifedipine and diltiazem.

\section{References}

1. Paulen ME, Folger SG, Curtis KM and Jamieson DJ: Contraceptive use among solid organ transplant patients: a systematic review. Contraception 82: 102-112, 2010.

2. Märker-Hermann E and Fischer-Betz R: Rheumatic diseases and pregnancy. Curr Opin Obstet Gynecol 22: 458-465, 2010.

3. Haw S, Shin MK and Haw CR: The efficacy and safety of long-term oral cyclosporine treatment for patients with atopic dermatitis. Ann Dermatol 22: 9-15, 2010.

4. Ramos-Casals M, Tzioufas AG, Stone JH, Sisó A and Bosch X: Treatment of primary Sjögren syndrome: a systematic review. JAMA 304: 452-460, 2010.

5. Zhang Y, Li X, Zhou Y, Wang X, Fan Y, Huang Y and Liu Y: Preparation and evaluation of poly(ethylene glycol)-poly(lactide) micelles as nanocarriers for oral delivery of cyclosporine A. Nanoscale Res Lett 5: 917-925, 2010.

6. Brandt C, Liman P, Bendfeldt H, et al: Whole blood flow cytometric measurement of NFATc1 and IL-2 expression to analyze cyclosporine A-mediated effects in T cells. Cytometry A 77: 607-613, 2010.

7. Ho MW, Deng B, Benoit S, et al: Comparison of dexamethasone and cyclosporine to selective protein kinase $\mathrm{C}$-theta inhibitor effects on blood IL-2 production and T cell activation. J Immunol 182: 35.32, 2009.

8. Salem NA, Salem EA, Maarouf AM, et al: Protective effect of trapidil and l-arginine against renal and hepatic toxicity induced by cyclosporine in rats. Ren Fail 32: 959-968, 2010.

9. Robert N, Wong GW and Wright JM: Effect of cyclosporine on blood pressure. Cochrane Database Syst Rev 20: CD007893, 2010.

10. Mancia G, De Backer G, Dominiczak A, et al: 2007 Guidelines for the Management of Arterial Hypertension: The Task Force for the Management of Arterial Hypertension of the European Society of Hypertension (ESH) and of the European Society of Cardiology (ESC). J Hypertens 25: 1105-1187, 2007.

11. Williams B, Poulter NR, Brown MJ, et al: Guideliness for management of hypertension: report of the fourth working party of the British Hypertension Society, 2004-BHS IV. J Hum Hypertens 18: 139-185, 2004 
12. Large WA, Saleh SN and Albert AP: Role of phosphoinositol 4,5-bisphosphate and diacylglycerol in regulating native TRPC channel proteins in vascular smooth muscle. Cell Calcium 45: 574-582, 2009

13. Ren C, Zhang J, Philipson KD, Kotlikoff MI, Blaustein MP and Matteson DR: Activation of L-type $\mathrm{Ca}^{2+}$ channels by protein kinase $C$ is reduced in smooth muscle-specific $\mathrm{Na}^{+} / \mathrm{Ca}^{2+}$ exchanger knockout mice. Am J Physiol Heart Circ Physiol 298 : $1484-1491,2010$

14. Misior AM, Deshpande DA, Loza MJ, Pascual RM, Hipp JD and Penn RB: Glucocorticoid- and protein kinase A-dependent transcriptome regulation in airway smooth muscle. Am J Respir Cell Mol Biol 41: 24-39, 2009.

15. Rainbow RD, Norman RI, Everitt DE, Brignell JL, Davies NW and Standen NB: Endothelin-I and angiotensin II inhibit arterial voltage-gated $\mathrm{K}^{+}$channels through different protein kinase $\mathrm{C}$ isoenzymes. Cardiovasc Res 83: 493-500, 2009

16. Fomin VP, Kronbergs A, Gunst S, Tang D, Simirskii V, Hoffman M and Duncan RL: Role of protein kinase C in regulation of $\left[\mathrm{Ca}^{2+}\right](\mathrm{I})$ and force in human myometrium. Reprod Sci 16: 71-79, 2009.

17. von Burstin V, Xiao L and Kazanietz MA: Bryostatin 1 inhibits phorbol ester-induced apoptosis in prostate cancer cells by differentially modulating protein kinase $\mathrm{C}(\mathrm{PKC})$ translocation and preventing PKC-mediated release of tumor necrosis factor- $\alpha$. Mol Pharmacol 78: 325-332, 2010

18. Yang G, Li T, Xu J and Liu L: PKC plays an important mediated effect in arginine vasopressin induced restoration of vascular responsiveness and calcium sensitization following hemorrhagic shock in rats. Eur J Pharmacol 628: 148-154, 2010.

19. Magno AL, Ward B and Ratajczak T: The calcium-sensing receptor: a molecular perspective. Endocr Rev 32: 3-30, 2011

20. Camello-Almaraz C, Macias B, Gomez-Pinilla PJ, et al: Developmental changes in $\mathrm{Ca}^{2+}$ homeostasis and contractility in gallbladder smooth muscle. Am J Physiol Cell Physiol 296 : 783-791, 2009

21. Buraei $Z$ and Yang J: The beta\} subunit of voltage-gated $\mathrm{Ca}^{2+}$ channels. Physiol Rev 90: 1461-1506, 2010.

22. Berridge MJ: Inositol trisphosphate and calcium signalling mechanisms. Biochim Biophys Acta 1793: 933-940, 2009.

23. Vaithianathan T, Narayanan D, Asuncion-Chin MT, Jeyakumar LH, Liu J, Fleischer S, Jaggar JH and Dopico AM: Subtype identification and functional characterization of ryanodine receptors in rat cerebral artery myocytes. Am J Physiol Cell Physiol 299: 264-278, 2010.

24. Dobrev D and Wehrens XH: Calmodulin kinase II, sarcoplasmic reticulum $\mathrm{Ca}^{2+}$ leak, and atrial fibrillation. Trends Cardiovascular Med 20: 30-34, 2010.

25. Lohmann C: Calcium signaling and the development of specific neuronal connections. Prog Brain Res 175: 443-452, 2009.

26. Miranda L, Carpentier S, Platek A, et al: AMP-activated protein kinase induces actin cytoskeleton reorganization in epithelia cells. Biochem Biophys Res Commun 396: 656-661, 2010.

27. Kenakin T: Pharmacologic Analysis of Drug-receptor Interaction. Raven Press, 1997.
28. Van Rossum J: Cumulative dose-response curves. Technique for the making of dose-responses curves in isolated organs and the evaluation of drugs parameters. Arch Int Pharmacodyn 143: 299-330, 1963

29. El-Mas MM, Omar AG, Helmy MM and El-Din MM: Modulation of cyclosporine-induced hypertension by central endothelial and neuronal nitric oxide synthases. FASEB J 24: 959, 2010.

30. Cottet-Maire F, Avdonin PV, Roulet E, Buetler TM, Mermod N and Ruegg UT: Upregulation of vasopressin V1A receptor mRNA and protein in vascular smooth muscle cells following cyclosporin A treatment. Br J Pharmacol 132: 909-917, 2001.

31. Wang GJ, Lin YL, Chen CH, Wu XC, Liao JF and Ren J: Cellular calcium regulatory machinery of vasorelaxation elicited by petasin. Clin Exp Pharmacol Physiol 37: 309-315, 2010.

32. Scarselli M and Donaldson JG: Constitutive internalization of $\mathrm{G}$ protein-coupled receptors and $\mathrm{G}$ proteins via clathrin-independent endocytosis. Biol Chem 284: 3577-3585, 2009.

33. Li YF, Cao XJ, Bai XY, Lin SP and Shi ST: Change of expression of renal alpha1-adrenergic receptor and angiotensin II receptor subtypes with aging in rats. Aging Clin Exp Res 22: 123-128, 2010.

34. Ramzy D, Wallen J, Badiwala MV, et al: Endothelin-1 antagonism and nitric oxide augmentation prevents cyclosporine-induced vasomotor impairment. J Heart Lung Transplant 30: 77-85, 2011.

35. Gonzalez-Villalobos RA, Satou R, Seth DM, Semprun-Prieto LC, Katsurada A, Kobori H and Navar LG: Angiotensin-converting enzyme-derived angiotensin II formation during angiotensin II-induced hypertension. Hypertension 53: 351-355, 2009

36. Shin DH, Park HM, Jung KA, et al: The NRF2-heme oxygenase-1 system modulates cyclosporin A-induced epithelial-mesenchymal transition and renal fibrosis. Free Radic Biol Med 48: 1051-1063, 2010.

37. Landmark $\mathrm{K}$ and Reikvam A: Calcium antagonists in treatment of hypertension. Tidsskr Nor Laegeforen 129: 2488-2489, 2009.

38. Carrier M, Tronc F, Stewart D, Nattel S and Pelletier LC: Blockade of cyclosporine-induced vasoconstriction by the calcium channel blocker diltiazem in dogs. J Thorac Cardiovasc Surg 106: 487-490, 1993.

39. Hami M, Mojahedi MJ, Naghibi M, Shakeri MT and Sharifipour F: Cyclosporine trough levels and its side effects in kidney transplant recipients. Iran J Kidney Dis 4: 153-157, 2010.

40. Dorababu M, Nishimura A, Prabha T, Naruhashi K, Sugioka N, Takada K and Shibata N: Effect of cyclosporine on drug transport and pharmacokinetics of nifedipine. Biomed Pharmacother 63: 697-702, 2009

41. Derosa G and Maffioli P: Effects of amlodipine plus atorvastatin association in hypertensive hypercholesterolemic patients. Expert Rev Cardiovasc Ther 8: 835-843, 2010.

42. van der Schaaf MR, Hené RJ, Floor M, Blankestijn PJ and Koomans HA: Hypertension after renal transplantation. Calcium channel or converting enzyme blockade? Hypertension 25: 77-81, 1995.

43. Chanard J, Toupance O, Lavaud S, Hurault de Ligny B, Bernaud C and Moulin B: Amlodipine reduces cyclosporin-induced hyperuricaemia in hypertensive renal transplant recipients. Nephrol Dial Transplant 18: 2147-2153, 2003. 